\title{
Helminth Parasites of Red Lionfish, Pterois volitans from the Veracruz Coral Reef System, Mexico, Southern Gulf of Mexico
}

\author{
Jesús Montoya-Mendoza ${ }^{1}$, Tomás Camarena-Luhrs² ${ }^{2}$, María del Refugio Castañeda-Chávez ${ }^{1}$ \\ \& Fabiola Lango-Reynoso ${ }^{1}$ \\ ${ }^{1}$ Tecnológico Nacional de México, Instituto Tecnológico de Boca del Río, Veracruz, México \\ ${ }^{2}$ Parque Nacional Sistema Arrecifal Veracruzano, Comisión Nacional de Áreas Naturales Protegidas, México \\ Correspondence: Jesús Montoya-Mendoza, Laboratorio de Investigación Acuícola Aplicada, Tecnológico \\ Nacional de México, Instituto Tecnológico de Boca del Río, Carretera Veracruz-Córdoba km 12, Boca del Río, \\ 94290, Veracruz, México. Tel: 52-229-690-5010. E-mail: jesusmontoya@itboca.edu.mx
}

Received: July 24, 2017

Accepted: September 27, 2017

Online Published: October 15, 2017

doi:10.5539/jas.v9n11p30

URL: https://doi.org/10.5539/jas.v9n11p30

The research is financed by Parque Nacional Sistema Arrecifal Veracruzano CONANP-MEXICO and the Research Line: Procesos y Tecnologías para Sistemas Ambientales en los Ecosistemas Costeros Marinos, Maestría en Ciencias en Ingeniería Ambiental. Tecnológico Nacional de México/Instituto Tecnológico de Boca del Río.

\begin{abstract}
A helminthological survey was conducted on 78 red lionfish, Pterois volitans, collected in the Veracruz Reef System National Park (VRSNP). Register: trematodes (5 spp.), cestodes (1), and nematodes (2). Prevalence per species $<30 \%$ and mean intensity $<6.0$. Three new host records are reported herein. The red lionfish is infected by species of endoparasites generalist and played a role as accidental host.
\end{abstract}

Keywords: endoparasites, lionfish

\section{Introduction}

Today, invasive species are one of the most challenging environmental problems, e.g. Cyprinus carpio or Oreochromis mossambicus. These species invade territories out of their natural distribution areas, disturbing and displacing native species through predation, competence and disease transmission (Lockwood et al., 2007). The red lionfish, $P$. volitans, came from the Indo-Pacific Ocean, and for more than 30 years has sprayed across the West Atlantic Coast, Caribbean (Morris et al., 2008; Morris, 2012), and Southern Gulf of Mexico (Santander-Monsalvo et al., 2012; Wakida-Kusunoki \& Amador del Ángel, 2015). This organism has been studied from different perspectives, to take actions aimed to control and mitigate its impact on native biota and habitat in general. Studying one of these facets, helminthiasis and its infections, has shown that $P$. volitans participates in parasite life-cycles as accidental, paratenic or intermediate host (Simmons, 2014). This conclusion is supported by records of 30 helminth species from groups such as digeneans, monogeneans, cestodes, nematodes and acanthocephalans (Bullard et al., 2011; Simmons, 2014; Ramos-Ascherl et al., 2015; Sellers et al., 2015; Fogg et al., 2016). In general, helmiths have low prevalence and low abundance, due to the introduction time of the invasive species, the low susceptibility of the host to be infected by native parasites, and consumption of vectors with infective stages (Torchin et al., 2003; Torchin \& Mitchell, 2004; Vignon \& Sasal, 2010). Despite being an invasive species, lionfish have also acquired parasites from indigenous fish (Guegan \& Kennedy, 1993; Gendron et al., 2012). This study aims to pinpoint parasitic helminthes of this species, recently sighted in the reefs of Veracruz, Mexico.

\section{Methods}

Between May 2016 and March 2017, 78 lionfish (body length: 9.0-39.7 cm, weight: 15-1,063 g) were examined. The fish were captured with spear and SCUBA diving, in 15/22 reefs of the VRSNP, by personnel from the Marine Park of the National Commission of Natural Protected Areas (Comisión Nacional de Áreas Naturales Protegidas) (CONANP), framed within the Park activities against lionfish. These fish were transported into plastic containers with ice to the Applied Aquaculture Research Lab (Laboratorio de Investigación Acuicola 
Aplicada) (LIAA), of the Technology Institute of Boca del Río. They were examined 24 hours after capture, and specimens were identified under criteria described by Schultz (1986). The helminthological examination was conducted on all tissues and organs, excepting blood and bones, following Lamothe (1997). Parasites were placed in Petri dishes with saline solution, $0.65 \%$, fixed with hot $4 \%$ formaline, and preserved in vials with $70 \%$ alcohol. Trematodes and cestodes were stained with Mayer's carmine or Gomori's triple stain, and then dehydrated in a graded alcohol series, cleared with clove oil, and mounted whole in Canada balsam. Nematodes were in glycerin (Vidal-Martínez et al., 2001). Prevalence (percentage of infected hosts) and mean intensity of infection (mean number of parasites per infected fish) were calculated following Bush et al. (1997).

\section{Results and Discussion}

Eight parasite taxa, from three helminth groups, were recorded (one at species level, four at genus level, two at family, and one at group), as follows: 5 trematodes ( 3 adults, 2 metacercariae); 1 cestode (larva); and 2 nematodes ( 1 adult, 1 larvae); and three new host records are described (Table 1$)$. About $50 \%$ of taxa were adult stages. All parasites showed prevalence values $<30 \%$ and mean intensity $<6.0$ helminths per infected fish. Infection of red lionfish are mainly associated to their feeding habits, with the exception of the fins metacercariae. Six out of the eight taxa have previous records in local hosts, such as Lecithochirium floridense, Gonocercella sp., and Hysterothylacium sp., as well as by Didymozoidae metacercariae or Tetraphyllidae larvae in carangids and lutjanids (Montoya-Mendoza et al., 2014, 2016, 2017), confirms that in red lionfish, infections are accidental and caused by generalist helminth parasites, with low abundances and prevalences. Comparatively, the number of species found in this study is similar to that registered in different sites of the Gulf of Mexico and the Caribbean Sea, e.g., Eastern Florida Coast, USA (8 spp.) (Simmons, 2014), Cayman Islands (7), and the Bahamas (6); but lower than that recorded in Puerto Rico (13) (Ramos-Ascherl et al., 2015). Three new host records are provided, enrichening parasite records in red lionfish. P. volitans specimens from southern Gulf of Mexico have all characteristics of invasive species, and have been recorded for other sites of the Gulf of Mexico and Caribbean Sea (Torchin et al., 2003; Simmons, 2014; Ramos-Ascherl et al., 2015; Sellers et al., 2015; Fogg et al., 2016). It is probable that helminths recorded belong to other host fish, which are lionfish preys, and we do not rule out the possibility of lateral transference of nematode larvae, as described for helminths of other marine fish (Marcogliese, 2007). Finally, lionfish could also be a dead-end host for some species infecting them, due to the lack of natural predators.

Table 1. Infection parameters and site of infection of the helminth parasites of red lionfish, Pterois volitans, from the VRSNP, Veracruz, Mexico

\begin{tabular}{|c|c|c|c|c|}
\hline Helminth & Site & $\mathrm{n}(\%$ prevalence $)$ & Mean intensity $( \pm \mathrm{SD})$ & Range \\
\hline \multicolumn{5}{|l|}{ Trematoda } \\
\hline \multicolumn{5}{|l|}{ Adult } \\
\hline Lecithochirium floridense & intestine & $3(3.84)$ & $3.33 \pm 4.04$ & $1-8$ \\
\hline Gonocercella sp.* & gill & $1(1.28)$ & $1 \pm-$ & 1 \\
\hline Prosorhynchus sp.* & intestine & $3(3.84)$ & $2 \pm 1.73$ & $1-4$ \\
\hline \multicolumn{5}{|l|}{ Metacercariae } \\
\hline Didymozoidae gen. sp. & intestine & $14(17.94)$ & $2.64 \pm 3.67$ & $1-13$ \\
\hline Metacercaria & caudal fin & $2(2.56)$ & $6 \pm 7.07$ & $1-11$ \\
\hline \multicolumn{5}{|l|}{ Cestoda (larva) } \\
\hline Tetraphyllidea gen. sp. & intestine & $8(10.25)$ & $1.62 \pm 0.91$ & $1-3$ \\
\hline \multicolumn{5}{|l|}{ Nematoda } \\
\hline \multicolumn{5}{|l|}{ Adult } \\
\hline Pseudocapillaria (Pseudocapillaria) sp.* & intestine & $23(29.48)$ & $2.21 \pm 2.31$ & $1-11$ \\
\hline \multicolumn{5}{|l|}{ Larva } \\
\hline Hysterothylacium sp. & intestine & $2(2.56)$ & $1 \pm 0$ & $1-1$ \\
\hline
\end{tabular}

Note. * New host record; n, number of hosts infected. 


\section{References}

Bullard, S. A., Barse, A. M., Curran, S. S., \& Morris, J. A. Jr. (2011). First record of a digenean from invasive lionfish, Pterois cf. volitans, (Scorpaeniformes: Scorpaenidae) in the northwestern Atlantic Ocean. Journal of Parasitology, 97, 833-837. http://doi.org/10.1645/GE-2746.1

Bush, A. O., Lafferty, K. D., Lotz, J. M., \& Shostak, A. W. (1997). Parasitology meets ecology on its own terms: Margolis et al. revisited. Journal of Parasitology, 83, 575-583. http://doi.org/10.2307/3284227

Fogg, A. Q., Ruiz, C. F., Curran, S. S., \& Bullard, S. A. (2016). Parasites from the red lionfish, Pterois volitans from the Gulf of Mexico. Gulf and Caribbean Research, 27, SC1-SC5. https://doi.org/10.18785/gcr.2701.07

Gendron, A., Marcogliese, D., \& Thomas, M. (2012). Invasive species are less parasitized than native competitors, but for how long? The case of the round goby in the Great Lakes-St. Lawrence Basin. Biological Invasions, 14, 367-384. https://doi.org/10.1007/s10530-011-0083-y

Guegan, J. F., \& Kennedy, C. R. (1993). Maximum local helminth parasite community richness in British freshwater fish: A test of the colonization time hypothesis. Parasitology, 106, 61-100. https://doi.org/10.1017/S0031182000074862

Lamothe, A. R. (1997) Manual de técnicas para preparar y estudiar los parásitos de animales silvestres. Edición Reimpresa, México.

Lockwood, J. L., Hoopes, M. F., \& Marchetti, M. P. (2007). Invasion Ecology. Malden Massachusetts, Blackwell

Marcogliese, D. J. (2007). Evolution of parasitic life in the ocean: Paratenic hosts enhance lateral incorporation. Trends in Parasitology, 23, 519-521. https://doi.org/10.1016/j.pt.2007.09.001

Montoya-Mendoza, J., Castañeda-Chávez, M. R., Lango-Reynoso, F., \& Rojas-Castañeda, S. (2016). Helminth parasites of lane snapper, Lutjanus synagris from Santiaguillo reef, Veracruz, Mexico. Journal of Agricultural Science, 8, 81-88. https://doi.org/10.5539/jas.v8n11p81

Montoya-Mendoza, J., Jiménez-Badillo, L., Salgado-Maldonado, G., \& Mendoza-Franco, E. F. (2014). Helminth parasites of the red snapper, Lutjanus campechanus (Perciformes: Lutjanidae) from the reef Santiaguillo, Veracruz, Mexico. Journal of Parasitology, 100, 868-872. https://doi.org/10.1645/13-429.1

Montoya-Mendoza, J., Salgado-Maldonado, G., Favila-Castillo, M. E., Vázquez-Hurtado, G., \& Castañeda-Chávez, M. R. (2017). Communities of helminth parasites in five Carangidae species from the Coast of Veracruz, Mexico, Southern Gulf of Mexico. Global Journal of Science Frontier Research, 17(1), 7-18. Retrieved from https://journalofscience.org/index.php/GJSFR/article/view/1976

Morris, J. A. Jr. (Ed.). (2012). Invasive lionfish: A guide to control and management. Special publication series number 1. Gulf and Caribbean Fisheries Institute, Marathon, Florida, USA. https://oi.org/10.1039/ 9781849734967

Morris, J. A. Jr., Akins, J. L., Barse, A., Cerino, D., Freshwater, D. W., Green, S. J., et al. (2008). Biology and ecology of the invasive lionfishes, Pterois miles and Pterois volitans. Proceedings of the $61^{\text {st }}$ Gulf and Caribbean Fisheries Institute (pp. 409-413). Retrieved from http://aquaticcommons.org/14849/1/ GCFI 61-64.pdf

Ramos-Ascherl, Z., Williams, E. H., Bunkley, W. L., Tuttle, L. J., Sikkel, P. C., \& Hixon, M. A. (2015). Parasitism in Pterois volitans (Scorpaenidae) from coastal waters from Puerto Rico, the Cayman Islands and the Bahamas. Journal of Parasitology, 101, 50-56. https://doi.org/10.1645/13-422.1

Santander-Monsalvo, J., López-Huerta, I., Aguilar-Perera, A., \& Tuz-Sulub, A. (2012). First record of the red lionfish (Pterois volitans [Linnaeus, 1758]) off the coast of Veracruz, Mexico. BioInvasions Records, 1(2), 121-124. https://doi.org/10.3391/bir.2012.1.2.07

Schultz, E. T. (1986). Pterois volitans and Pterois miles: Two valid species. Copeia, 3, 686-690. https://doi.org/ $10.2307 / 1444950$

Sellers, A. J., Ruiz, G. M., Leung, B., \& Torchin, M. E. (2015). Regional variation in parasite species richness and abundance in the introduced range of the invasive lionfish, Pterois volitans. PLoS ONE, 10, e0131075. https://doi.org/10.1371/journal.pone.0131075

Simmons, K. R. (2014). Evidence of the enemy release hypothesis: Parasites of the lionfish complex (Pterios volitans and P. miles) in the Western North Atlantic, Gulf of Mexico, and Caribbean Sea (Master's thesis, 
Nova Southeastern University, NSUWorks, Oceanographic Center). Retrieved from http://nsuworks. nova.edu/occ_stuetd/2

Torchin, M. E., \& Mitchell, C. E. (2004). Parasites, pathogens, and invasions by plants and animals. Frontiers in Ecology and the Environment, 2, 183-190. https://doi.org/10.1890/1540-9295(2004)002[0183:PPAIBP] 2.0.CO;2

Torchin, M. E., Lafferty, K. D. A., Dobson, P., Mckenzie, V. J., \& Kuris, A. M. (2003). Introduced species and their missing parasites. Nature, 421, 628-630. https://doi.org/10.1038/nature01346

Vidal-Martínez, V. M., Aguirre-Macedo, M. L., Scholz, T., González-Solís, D., \& Mendoza-Franco, E. F. (2001). Atlas of the helminth parasites of cichlid fish of Mexico. Academia, Praha, Czech Republic.

Vignon, M., \& Sasal, P. (2010). Fish introduction and parasites in marine ecosystems: A need for information. Environmental Biology of Fishes, 87, 1-8. https://doi.org/10.1007/s10641-009-9553-9

Wakida-Kusunoki, A. T., \& Amador del Ángel, L. E. (2015). First record of the red lionfish, Pterois volitans, on the coast of Tabasco, Mexico. Hidrobiológica, 25, 307-309.

\section{Copyrights}

Copyright for this article is retained by the author(s), with first publication rights granted to the journal.

This is an open-access article distributed under the terms and conditions of the Creative Commons Attribution license (http://creativecommons.org/licenses/by/4.0/). 